\author{
(online) $=$ ISSN $2285-3642$ \\ ISSN-L = $2285-3642$ \\ Journal of Economic Development, Environment and People \\ Volume 3, Issue 1, 2014 \\ URL: http://jedep.spiruharet.ro \\ e-mail: office jedep@spiruharet.ro
}

\title{
Management Strategies and Environmental Accounting in Economic Entities. A Contribution to Sustainable Development
}

\author{
Professor Cicilia IONESCU, $\mathrm{PhD}^{1}$, Lecturer Maria Ramona Chivu, $\mathrm{PhD}^{2}$, \\ Assistant Lecturer Marin Chivu PhD ${ }^{3}$ \\ ${ }^{1}$ Spiru Haret University, str. Fabricii, no. 46 G, sect. 6, Bucharest \\ ciciliaionescu@yahoo.com \\ ${ }^{2}$ Spiru Haret University, str. Fabricii, no. 46 G, sect. 6, Bucharest \\ chivumariaramona@yahoo.com \\ ${ }^{3}$ Spiru Haret University, str. Fabricii, no. 46 G, sect. 6, Bucharest \\ chivu marin@yahoo.com
}

\begin{abstract}
The economic transactions made in an causes interactions with the environment, in some cases occurring adverse environmental effects. Progressive degradation of the natural environment and increasing social concern before this event, converted protect the environment in one of the most important strategic actions amendment requiring entities to include consideration of environmental issues.

The general objective of this study is to analyze business practices related to environmental issues, both in its accounting treatment and environmental management strategies to entities that perform activities of environmental degradation.
\end{abstract}

Keywords: environmental management strategies, environmental accounting, environmental degradation, environmental protection.

JEL Codes: M41, M48, Q20, Q51, Q56, N27.

\section{Introduction}

During our training and in our work as professionals, we met with many fields of study and analysis, particularly those related to accounting and management. In the study, we found that accounting is undergoing a continuous transformation, knowing and analyzing a number of areas or industries that complement.

In recent years, were presented with a special sensitivity, natural environment issues. However, due to problems caused by waste produced by industries in its production process, which caused great loss of natural and serious risks to the population.

Air, water and soil, in general, have always been free and plentiful. Currently, they can not be. Taking care of them requires a cost. Companies must produce without losing sight of the environment, something that forces them to invest in an item unusual environmental costs. Environmental costs usually are not reflected in the financial information. In our opinion, these should reflect economic reality and how the environment is affected and ultimately provide useful information for making management decisions. 


\author{
(online) = ISSN $2285-3642$ \\ ISSN-L = 2285-3642 \\ Journal of Economic Development, Environment and People \\ Volume 3, Issue 1, 2014 \\ URL: http://jedep.spiruharet.ro \\ e-mail: office jedep@spiruharet.ro
}

Global environmental standards have been developed that attempts to protect the environment by reducing environmental pollution. For this reason, both macroeconomic and microeconomic born an interesting concept to be analyzed from the point of view of our profession, environmental accounting. Environmental Accounting is a recent branch of accounting, perhaps because it is frequently encountered among various professional researchers and organizations normalizing. Although the macroeconomic point of view is a concept widely used in micro-level has not been sufficiently treated, being found only in developed countries and in some Latin American countries, which began to consider this concept as a subject and an important area of analysis and study.

We ask the following questions: What would choose business and society, if there were no resources to exploit and produce? How can an economy survive without the natural environment, which gives us all? This, surely lead to solutions to environmental problems, to achieve efficient environmental management and resource protection regulations for businesses and conscience of society must play a controller because the end, is the recipient of the products made by the authorities and by nature.

\title{
2. Approach to environmental issues in economic entities and at the macroeconomic level
}

Environmental problem lies in the misuse of resources by society. There are very few companies that analyze environmental degradation, as this would involve increased costs and environmental costs, and many are not willing to sacrifice some of its utilities.

For many, the exploitation of the environment is widely associated with economic growth, aided by technology. The greatest responsibility of impoverishment of nature as a result of environmental pollution are the most important industries and multinational companies located at the top of the economy for the great technological development and production, in addition, are not willing to bring radical solutions to problems that lead to reducing its capacity to invest and monopolizing prices.

If until recently the waste emitted by furnaces during the production process, were a symbol of progress, now, due to pollution and the growing concern for the natural environment has been that companies have to change their views on what they thought it was a picture of a large and important industry, changing radically the image regarding non-contamination and environmental concern.

A change in the new form of patterns of production and consumption in the global economy directly affects the GDP of any country, given that most of its activities, both in production, consumption and service provision, directly threaten the environment either by the use of space, soil, resources and pollution generated by the production and its consumption. You can not imagine saving the environment without causing an increase in prices of products and production stagnation? 


\author{
(online) = ISSN $2285-3642$ \\ ISSN-L = $2285-3642$ \\ Journal of Economic Development, Environment and People \\ Volume 3, Issue 1, 2014 \\ URL: http://jedep.spiruharet.ro \\ e-mail: office jedep@spiruharet.ro
}

\title{
3. Sustainable development
}

Economic and social development is that which meets the needs of the present without compromising future generations them to meet their own needs. Thus, we ask: How long life left on earth? The response so far has no solution because renewable and non-renewable resources, have not a method of depreciation to allocate an exact time of total consumption, much less a time of restoration and renewal.

Following these statements, the concept of sustainable development rethinks the idea that man is the center of economy and rather viewed as an element of the system.

But what is obvious is the need to improve the lives of disadvantaged countries by redistributing income thus leading to a global economic balance, growing population pressure controlled to reduce resource costs.

\section{Environmental Management}

In recent years, companies have shown an increasing interest to help solve environmental problems which disrupt society in order to achieve ecological improvement. To develop an environmental policy in an orderly developed environmental management systems.

An environmental management system is a means to collect all existing programs that can be managed for environmental compliance, training, accounting and control in an organized (Tiberti: 2008). It is a management tool of analysis, of the impact of an organization on the environment (Chavan: 2005). It provides an appropriate structure for the planning and implementation of environmental protection measures. In an environmental management system is necessary for an organization to identify its effects on the environment, while promoting a continuous improvement environment (Rowland-Jones et al., 2005).

To implement an environmental management system are used international standards which aim supporting organizations in their efforts to achieve improvement of environmental performance, satisfaction of stakeholders and benefiting from an effective environmental management.

Some of the most important tools in this respect are the standards for environmental management systems such as the EMAS (the European Eco-Management and Audit Scheme). EMAS is the European environment management tool designed for help organizations continuously improve environmental performance by integrating the concept of sustainable development.

Also are used ISO standards (Intenational Organization for Standardization), these being the international standard used to implement an environmental management system (EMAS). 


\author{
(online) = ISSN $2285-3642$ \\ ISSN-L = $2285-3642$ \\ Journal of Economic Development, Environment and People \\ Volume 3, Issue 1, 2014 \\ URL: http://jedep.spiruharet.ro \\ e-mail: office jedep@spiruharet.ro
}

\title{
5. Accounting and environmental issues
}

Environmental issues is the result of ecological crisis that could not be stopped or controlled. Environmental degradation, now more than ever endangered future of the human species. Even some scientists have come to the apocalyptic forecasts, if nothing is done to resolve this situation.

Preservation and conservation of biosphere, expanding the idea of perception of quality of life, with all its implications and the new concept of sustainable development, are the visible face of the current position, which was established as a response to environmental issues.

What can expect from this and subsequent revision of concepts and ideas, is the emergence of a new model for information systems as they have to enable it to adequately reflect the situation or context information for the analysis and evaluation of new perspectives designed according to different relevant information to users.

A good demonstration of this new perspective is given the sharp decline of thought, which we have society, regarding the fact that the work creates jobs, income, prosperity and wealth, but work such as the ecology, not necessarily generate quality of life.

\subsection{Types of environmental accounting:}

a) National Accounts. It is a macroeconomic measure. The term environmental accounting refers to the national economy. For example: The term environmental accounting can be used in physical or monetary units according to the nation's consumption of natural resources, being renewable or nonrenewable being. In this context, environmental accounting has been called natural resource accounting.

b) Financial Accounting. Relating to financial statements, which are based on International Financial Reporting Standards (IFRS) and Generally Accepted Accounting Principles. In this context, environmental accounting refers to estimating and reporting environmental responsibility and cost of financial terms.

c) Management Accounting. It is the process of identification, recollection and analysis of information, mainly for domestic purposes. It aims to manage costs, in particular to take account of administrative decisions in production and others.

Sarkis et al. (2006) indicates that the objective of environmental accounting is to provide accurate information and understandable to those responsible, to enable better decision making on matters affecting the financial health and the environment.

Environmental management accounting is a tool for identifying, collecting and analyzing information related to costs absorbed internally by the company, on the environment, in particular the costs associated with the waste of raw materials and production costs, elimination and outlet waste (OECD: 2005).

Gray et. al. (2001) suggest that environmental accounting should cover various issues, such as accounting for obligations / contingent risks, accounting for revaluation of assets and capital protection, analysis of costs in areas such as the energy, waste and environment, valuation of investments to include 


\author{
(online) $=$ ISSN $2285-3642$ \\ ISSN-L = $2285-3642$ \\ Journal of Economic Development, Environment and People \\ Volume 3, Issue 1, 2014 \\ URL: http://jedep.spiruharet.ro \\ e-mail: office jedep@spiruharet.ro
}

environmental factors, assessing the costs and benefits of environmental improvement programs, development of accounting techniques that express assets and liabilities, the costs of ecological and development of new accounting systems and information .

Many organizations have a responsibility to regulate the accounting profession have said their views on this issue, such as:

- EPA (Environmental Protection Agency, 1995), addresses issues related to environmental issues in various ways, such as the definition of terms, classification of costs, environmental accounting applications certain industries ;

- ISAR ( Corporate Accounting Transparency, UNCTAD , 1998), establishes standards and criteria for consideration of ecological concepts of operations ;

- EU Recommendation 2001/453 regarding the accounting treatment of resource flows from environmental activities;

- ICAC, in its resolution of 03.25.2002, is regarded as a pioneer in environmental matters in Europe. Are addressed in detail all transactions from enterprise interaction with the environment, establishing the criteria for analysis.

\title{
6. Contabilitatea financiară tradițională și contabilitatea de mediu
}

How differ financial cotabilitatea traditional from environmental accounting? Traditional financial accounting measures the financial results from human consumption of capital resources. Environmental accounting oriented environmental protection measures, measures of natural capital resources employed in production.

In the case of the company's management, it is desirable that the beginning of the implementation of environmental accounting criteria, to follow the following steps:

- The company must develop policies regarding environmental protection;

- Make plans and to design structures for such political action;

- Establish criteria for quantification and measurement, as appropriate;

- Establish managerial actions designed to manage and monitor results;

- Keep the owners, the government and the community in relation to achievements.

Challenges of environmental accounting has to be solved are: improving communication, improving standards of recording and accounting management, improving the contribution accounting practices in terms of environmental management in companies and, ultimately, decontamination balances that omits assets currently used and must be measured and recorded.

\section{Accounting relationships between the entity and its environment}

Environmental Accounting can be defined as part of the accounting applied, whose goal is the accounting relationship between an entity and its environment, those that lead to differences between macro and micro accounting. 


\author{
(online) $=$ ISSN $2285-3642$ \\ ISSN-L = $2285-3642$ \\ Journal of Economic Development, Environment and People \\ Volume 3, Issue 1, 2014 \\ URL: http://jedep.spiruharet.ro \\ e-mail: office jedep@spiruharet.ro
}

If Traditionally in micro accounting, to delineate entity is starts from the legal criteria (legal form of the entity, applicable law, etc..), in terms of environment, the entity is defined through technical analysis cycle product life and their activities, that is, from the design to eliminate all negative effects caused by the consumption of products or performance of activities. Moreover, the environment of an entity can be defined as the natural environment or their environment, including, in this second case, the natural environment, cultural and social entity over a period of time.

The possible combinations of these two basic concepts, entity and environment permit the establishment of at least three alternatives for the conceptual framework:

1. When opting for delimiting entity by legal criteria and the environment as a natural environment, environmental accounting conceptual framework is based on the traditional economy which economic science is independent of any environmental considerations except for two issues: the nature as the manufacturing economic resources (eg, resources that can be measured, appropriated, used and processed) and receivers of waste. Therefore, the information that it provides environmental accounting treats the classical principle of the entity and reduce at the additional inputs necessary to prevent, reduce and eliminate pollution and undesirable outputs (waste, emissions, discharges). This is the position adopted in the Financial Accounting Standards.

2. If the criterion for delimitation of the entity resulting from life cycle analysis of products and activities and environment is understood as living environment, the conceptual framework is based on the green economy, where the economic system is a subsystem of the environment in line with standards and continuous interaction with him. In this case, environmental accounting requires a new principle of the entity, which provides information about all types of social inputs and outputs. This position is most prevalent among those who promote the development of environmental accounting in the field of social responsibility.

3. Regarding the third alternative, conceptual framework has sufficient flexibility to adapt to the objectives set out above, of the accounting information required. This approach, typical management accounting allows the combination of different criteria for the delimitation of the entity and the environment, applying, as just indicated, depending on the objectives of accounting information. In this case, the conceptual framework is based on environmental economics (intermediate position between the traditional economy and the green economy), for which the economic system is related to and limited by the system environment. This alternative is a series of standards ISO 14000 (1996), 19000 (2003), EU EMAS regulations (2001).

Developing research in accounting and other various disciplines (chemistry, biology, engineering, etc.) growing concern of the standardization bodies and entities (economic and technical) and expanding environmental accounting activities, calls for agreement, in terms of fundamentals and common language and interdisciplinary. 


\author{
(online) $=$ ISSN $2285-3642$ \\ ISSN-L = $2285-3642$ \\ Journal of Economic Development, Environment and People \\ Volume 3, Issue 1, 2014 \\ URL: http://jedep.spiruharet.ro \\ e-mail: office jedep@spiruharet.ro
}

\title{
8. The global trend
}

In searching for information, it was found that in developed countries accounting has already been linked to environmental issues formally, so we can call countries like Germany, Scotland, Spain, Argentina, the United States, where these issues are taken into account and realize even research studies underway, where actively participates in various organizations among which tax authorities and reputable companies. To summarize, we can say that we are familiar with terms such as environmental accounting, environmental management accounting, green accounting, or green accounting.

\section{Conclusions}

Changes lived day after day, are consistently those drives improvement and implementing new methods for future requirements. Otherwise, the company may lose competitiveness and, in some cases, may disappear from lack of proper management of the environment.

We believe that they performed certain actions to reduce environmental impacts. However, it requires a greater commitment to sustainable development.

The most used strategies, applied of environmental managers, refers, in most cases, at the legal aspects. Environmental policies used by managers are not formally implemented. Many of them have used isolated measures to correct negative externalities, in particular in accordance with the regulations in this area.

From an accounting perspective have taken several actions were issued proposals and have generated numerous documents, but their practical application is far from theoretical postulates. Discrepancies between academic language and entrepreneurial behavior manifests reality distancing environmental issues.

Companies do not keep accounts by identifying the operations on the environment. Financial elements on the environment, are presented in conjunction with other accounting items, therefore, there is no information to assist in the calculation of the environment result.

In the total capital is important to include natural capital as a priority information system of national accounts, since it is considered controlling production processes and consumption of resources, being more accurate and significant preventive quality. 


\author{
(online) $=$ ISSN $2285-3642$ \\ ISSN-L = $2285-3642$ \\ Journal of Economic Development, Environment and People \\ Volume 3, Issue 1, 2014 \\ URL: http://jedep.spiruharet.ro \\ e-mail: office jedep@spiruharet.ro
}

\title{
Selected Bibliography:
}

[1] Chavan M. (2005), An appraisal of enviroment management system. A competitive advantage for small businesses, Management of Enviromental Quality,. Vol. 16, Issue 5, pp.444-463;

[2] Gray R., Bebbington J., Walters D., (2001), Contabilidad y Auditoria Ambiental. [Accounting for the Environment] trad. de Samuel Mantilla. Litoperla Impresora Ltda. Colombia. Primera reimpresión;

[3] OCDE (Organizațion para la Cooperațion y el desarrollo economico 2005), El medio ambiente y las líneas directrices de la OCDE para empresas multinacionales. Herramientas y enfoques empresariales. Editions de l'Paris;

[4] Rowland J., Rhys P., Meinwren G., Malcolm (2005), An evaluation of current enviromental management systems as indicators of enviromental perfomance. Management of Environmental Quality: An International Journal. Vol 16, Issue 3, pp. 211-219;

[5] Sarkis, J., Meade L., Presley A. (2006), An activity based management methodology for evaluating business processes for environmntal sustainability;

[6] Tibert L. (2008), Establishing the Value of Environmental Policy, Industrial Engineer, Vol. 40, Issue 4, pp. S17S19 